\title{
ВПЛИВ ЛІНІЙНИХ ОЗНАК ЕКСТЕР'ЄРУ НА СТАН МОЛОЧНОЇ ПРОДУКТИВНОСТІ КОРІВ-ПЕРВІСТОК УКРАЇНСЬКИХ ЧОРНО-РЯБОЇ ТА ЧЕРВОНО-РЯБОЇ МОЛОЧНИХ ПОРІД
}

\author{
Хмельничий Леонтій Михайлович \\ доктор сільськогосподарських наук, професор \\ Сумський національний аграрний університет \\ ORCID: 0000-0001-5175-1291 \\ E-mail: khmelnychy@ukr.net \\ Вечорка Вікторія Вікторівна \\ кандидат сільськогосподарських наук, доцент \\ Сумський національний аграрний університет \\ ORCID: 0000-0003-4956-2074 \\ E-mail: vvvechorka@gmail.com
}

Дослідження проведені в аспекті визначення ступеню впливу лінійних ознак на рівень молочної продуктивності корів українських молочних порід. Експериментальні дані грунтуються на матеріалах, отриманих у стадах племінних заводів з розведення української чорно-рябої молочної породи АФ «Маяк» Золотоніського району Черкаської області та ТОВ «Владана» Сумського району Сумської області та господарствах з розведення української червоно-рябої молочної породи ПЗ АФ «Маяк» Черкаської області та ТОВ «Млинівський комплекс» Роменського району Сумської області. За даними дисперсійного аналізу встановлено достовірний вплив трьох груп лінійних ознак та загальної оцінки за 100 бальною системою на величину надою корів-первісток за 305 днів лактації. Встановлено, що надій первісток української чорно-рябої молочної породи племінного заводу «Маяк» залежить на 33,2\% від ознак, які у комплексі характеризують молочний тип, на 20,6\% - розвиток тулуба та на 19,9\% - морфологічних ознак вимені. Аналіз сили впливу лінійних ознак на рівень молочної продуктивності корів ПЗ «Владана» показав достовірний вплив групових комплексів ознак, що характеризують молочний тип, тулуб та вим'я відповідно на надій - 26,3\%, 12,6\% і 12,7\%. За оцінкою корів української червоно-рябої молочної породи найвищий ступінь впливу на мінливість надою первісток ПЗ «Маяк» $і$ ТОВ «Млинівський комплекс» спричинили ознаки, що характеризують молочний тип (25,7\% і 26,8\%), вим'я (20,4\% і 30,9\%) та загальна оцінка за екстер'єрний тun (27,4\% і 29,5\%) відповідно. Показники дисперсійного аналізу засвідчили, що величина надою корів-первісток обох порід підконтрольних стаддостатньою мірою залежить також від рівня оцінки описових ознак, особливо таких як висота, глибина тулуба, кутастість, ширина заду, постава тазових кінцівок, переднє та заднє прикріплення вимені, центральна зв'язка та переміщення. Вміст жиру в молоці не залежить від рівня оцінки як групових, так і описових ознак. Наявність впливу лінійних ознак на величину надою корів-первісток свідчить про ефрективність селекції українських чорно-рябої та червоно-рябої молочних порід, оцінених за методикою лінійної класифрікації.

Ключові слова: чорно-ряба молочна, червоно-ряба молочна, сила впливу, лінійна оцінка типу, надій, коровапервістка.

DOI: https://doi.org/10.32845/bsnau.lvst.2020.1.2

Перспектива подальшої інтенсифікації молочного скотарства передбачає підвищення продуктивних і племінних якостей тварин, впровадження прогресивних технологій і методів селекції, яким може сприяти лише високоефективне ведення цілеспрямованої селекційноплемінної роботи задля отримання високопродуктивних тварин з екстер'єрно-конституціональною міцністю, тварин, які володіють добре вираженим молочним типом i $\epsilon$ придатними до умов експлуатації на великих механізованих фермах та комплексах. У цьому аспекті відповідно чільне місце має приділятися оцінці тварин за екстер'єрним типом взагалі та лінійною класифікацією зокрема. Оскільки достеменно відомо, щоіснує тісний зв'язок лінійних ознак з продуктивністю тварин, який завдяки добору та підбору, з урахуванням результатів лінійної класифікації, сприятиме створенню високопродуктивних стад молочної худоби бажаного типу [1, 2, 8, 10, 11, 13].

Рівень розвитку ознак, які характеризують молочну продуктивність корів $€$ результатом комплексної дії двох груп основних чинників - спадкових та зовнішнього середовища. Спадковість забезпечує формування фенотипу, а фрактори середовища - можливості його

реалізації. Успадковуваність лінійних ознак відрізняється значною мінливістю $[7,15,14]$, яка за різними дослідженнями варіювала, залежно від породи, у межах 0,09-0,54 [16]; 0,06-0,63 [20]; 0,11-0,31 [18]; 0,099-0,453 [15].

Наприклад, за даними досліджень корів української червоно-рябої молочної породи встановлено рівень коефріцієнтів успадковуваності групових лінійних ознак, що характеризують молочний тип $\left(h^{2}=0,327\right)$, розвиток тулуба $\left(h^{2}=0,259\right)$, вимені $\left(h^{2}=0,396\right)$ та фрінальною оцінкою типу $\left(h^{2}=0,404\right)$ та описових ознак - висоти у крижах $\left(h^{2}=0,208\right)$, ширини грудей $\left(h^{2}=0,244\right)$, глибини тулуба $\left(h^{2}=0,268\right)$, кутастості $\left(h^{2}=0,384\right)$, ширини заду $\left(h^{2}=0,242\right)$, постави тазових кінцівок $\left(h^{2}=0,228\right)$, переднього $\left(h^{2}=0,255\right)$ та заднього $\left(h^{2}=0,216\right)$ прикріпленням вимені та центральної зв'язки $\left(h^{2}=0,284\right)[6]$.

Знання успадковуваності та ступеня впливу тих чи інших факторів дає змогу створювати тваринам відповідні умови, забезпечуючи тим самим реалізацію генетичного потенціалу продуктивності молочної худоби. У зв'язку з цим і виникла необхідність відокремлено визначати ступінь впливу кожного із цих чинників у загальній мінливості взятих для дослідження показників. Встановити силу впливу 
лінійних ознак на рівень розвитку молочної продуктивностікорів створених українських молочних порід $\epsilon$ достатньо актуальною проблемою, що й визначило мету наших досліджень.

Матеріали

та методи досліджень. Експериментальні дані ґрунтуються на матеріалах досліджень, отриманих у стадах племінних заводів 3 розведення української чорно-рябої молочної породи АФ «Маяк» Золотоніського району Черкаської області та ТОВ «Владана» Сумського району Сумської області, господарствах 3 розведення української червоно-рябої молочної породи ПЗ АФ «Маяк» Черкаської області та ТОВ «Млинівський комплекс» Роменського району Сумської області.

Оцінка екстер'єрного типу корів-первісток проводилась за методикою лінійної класифрікації [4] шляхом порівняння оцінюваної тварини з встановленим модельним типом. За 100бальною системою класифікації оцінка здійснювалася окомірно з урахуванням чотирьох комплексів селекційних ознак, що характеризують: вираженість молочного типу, розвиток тулуба, стан кінцівок та морфологічні якості вимені. До комплексу ознак включені згідно з рекомендаціями ICAR $[8,17]$ лінійні статі, які функціонально пов'язані між собою. Кожен екстер'єрний комплекс оцінювався незалежно та мав свій ваговий коефіцієнт у загальній оцінці тварини: молочний тип (МТ) - 15\%, тулуб (Т)
$-20 \%$; кінцівки (К) - 25\% та вим'я (B) - $40 \%$.

Силу впливу $\left(\eta_{x}^{2}\right)$ лінійних ознак на рівень молочної продуктивності корів-первісток вивчали методом однофакторного дисперсійного аналізу через співвідношення факторіальної дисперсії до загальної [5]. Достовірність отриманих даних оцінювали обчисленням похибок статистичних величин (S.E.) та критеріїв достовірності Фішера (F). Рівень вірогідності класифікували порівнянням зі стандартними значеннями критеріїв. Результати вважали статистично достовірними за першого $\mathrm{P}<0,05\left(^{1}\right)$, другого - $\mathrm{P}<0,01\left(^{(2)}\right.$ та третього - $\mathrm{P}<0,001\left(^{3}\right)$ порогів вірогідності. Статистичну обробку даних експериментальних досліджень проводили методами математичної статистики за формулами, наведеними Е.К. Меркурьевой [3] на ПК з використанням програмного забезпечення Microsoft Excel.

Результати досліджень. За даними дисперсійного аналізу встановлено достовірний вплив трьох із чотирьох існуючих групових лінійних ознак екстер'єрного типу та загальної оцінки на величину надою за 305 днів лактації у корів-первісток української чорно-рябої молочної породи племінного заводу «Маяк», оцінених за 100-бальною системою (табл. 1).

\section{Сила впливу лінійних ознак на рівень розвитку молочної продуктивності корів-первісток української чорно-рябої молочної породи П3 «Маяк»}

(Ступені свободи = 259)

\begin{tabular}{|l|c|c|c|c|c|}
\hline \multirow{2}{*}{ Ознаки екстер'єру } & Число & \multicolumn{2}{|c|}{ Надій } & \multicolumn{2}{|c|}{ Жир, \% } \\
\cline { 3 - 5 } & градацій & $\eta_{\mathrm{x}}^{2} \pm$ S.E. & $\mathrm{F}$ & $\eta_{\mathrm{x}}^{2} \pm \mathrm{S} . \mathrm{E}$. & $\mathrm{F}$ \\
\hline Ознаки, що характеризують: молочний тип & 11 & $0,332 \pm 0,036^{3}$ & 12,3 & $0,064 \pm 0,040$ & 1,69 \\
\hline тулуб & 11 & $0,206 \pm 0,039^{3}$ & 6,44 & $0,050 \pm 0,040$ & 1,30 \\
\hline кінцівки & 13 & $0,042 \pm 0,049$ & 0,89 & $0,037 \pm 0,049$ & 0,78 \\
\hline вим'я & 9 & $0,199 \pm 0,031^{3}$ & 7,78 & $0,041 \pm 0,032$ & 1,34 \\
\hline Загальна оцінка & 7 & $0,344 \pm 0,038^{3}$ & 14,2 & $0,075 \pm 0,042$ & 1,86 \\
\hline Описові ознаки: висота & 8 & $0,151 \pm 0,027^{3}$ & 6,37 & $0,031 \pm 0,028$ & 1,13 \\
\hline ширина грудей & 6 & $0,084 \pm 0,020^{3}$ & 4,63 & $0,012 \pm 0,020$ & 0,62 \\
\hline глибина тулуба & 6 & $0,143 \pm 0,019^{3}$ & 8,45 & $0,009 \pm 0,020$ & 0,44 \\
\hline кутастість & 7 & $0,357 \pm 0,021^{3}$ & 23,3 & $0,033 \pm 0,024$ & 1,44 \\
\hline положення заду & 7 & $0,008 \pm 0,024$ & 0,33 & $0,037 \pm 0,024$ & 1,61 \\
\hline ширина заду & 7 & $0,107 \pm 0,0243$ & 5,06 & $0,031 \pm 0,024$ & 1,35 \\
\hline кут скакального суглоба & 8 & $0,010 \pm 0,028$ & 0,35 & $0,059 \pm 0,028$ & 2,25 \\
\hline постава тазових кінцівок & 7 & $0,111 \pm 0,0243$ & 5,75 & $0,039 \pm 0,024$ & 1,69 \\
\hline кут ратиць & 8 & $0,052 \pm 0,028$ & 1,97 & $0,043 \pm 0,028$ & 1,59 \\
\hline переднє прикріплення вимені & 7 & $0,348 \pm 0,021^{3}$ & 22,5 & $0,028 \pm 0,024$ & 1,21 \\
\hline висота вимені ззаду & 8 & $0,134 \pm 0,027^{3}$ & 5,35 & $0,035 \pm 0,028$ & 1,30 \\
\hline центральна зв'язка & 8 & $0,102 \pm 0,028^{3}$ & 4,08 & $0,025 \pm 0,028$ & 0,91 \\
\hline глибина вимені & 7 & $0,032 \pm 0,024$ & 1,38 & $0,030 \pm 0,024$ & 1,28 \\
\hline розміщення передніх дійок & 8 & $0,104 \pm 0,028^{3}$ & 4,16 & $0,032 \pm 0,028$ & 1,20 \\
\hline розміщення задніх дійок & 9 & $0,110 \pm 0,032^{3}$ & 3,88 & $0,037 \pm 0,032$ & 1,20 \\
\hline довжина дійок & 6 & $0,007 \pm 0,020$ & 0,38 & $0,022 \pm 0,020$ & 1,15 \\
\hline переміщення (хода) & 6 & $0,042 \pm 0,020^{1}$ & 2,31 & $0,030 \pm 0,020$ & 1,55 \\
\hline вгодованість & 8 & $0,165 \pm 0,027^{3}$ & 7,08 & $0,079 \pm 0,028$ & 1,06 \\
\hline
\end{tabular}

Від ознак, що у комплексі характеризують вираженість молочного типу, надій корів-первісток залежить на $33,2 \%$, залежність надою від розвитку тулуба становить $20,6 \%$ та морфологічних ознак вимені - на 19,9\%. Від загальної оцінки типу корів-первісток рівень надою за лактацію залежить на $34,4 \%$ та вміст у ньому жиру - на $7,5 \%$.
Таблиця 1 
розвитком центральної зв'язки, розміщенням передніх та задніх дійок, а також вгодованістю тварин - показники варіювали в межах 0,102-0,165 з високим ступенем достовірностіза критерієм Фішера. Найвищий, хоча і недостовірний, показник сили впливу описових лінійних ознак на якісні характеристики молока, зокрема вміст у ньому жиру, виявлено за ознакою вгодованості - 7,9\%.

Аналіз сили впливу лінійних ознак на рівень молочної продуктивності корів української чорно-рябої молочної породи стада Північно-Східного регіону України ПЗ «Владана» за даними першої лактації (табл. 2) показав достовірний вплив групових комплексів ознак, що характеризують молочний тип, тулуб та вим'я відповідно на надій - 26,3\%, 12,6\% і 12,7\% та нижчий і недостовірний - на вміст жиру в молоці $-4,9 \%, 3,9 \%$ і 2,0\%.

Сила впливу лінійних ознак на рівень розвитку молочної продуктивності корів-первісток української чорно-рябої молочної породи ПЗ «Владана»

Таблиця 2 (Ступені свободи = 289)

\begin{tabular}{|c|c|c|c|c|c|c|}
\hline \multirow{2}{*}{\multicolumn{2}{|c|}{ Ознаки екстер'єру }} & \multirow{2}{*}{$\begin{array}{c}\text { Число } \\
\text { градацій }\end{array}$} & \multicolumn{2}{|c|}{ Надій } & \multicolumn{2}{|c|}{ Жир, \% } \\
\hline & & & $\eta_{x}^{2} \pm S . E$. & $\mathrm{F}$ & $\eta_{x}^{2} \pm S . E$. & $\mathrm{F}$ \\
\hline \multicolumn{2}{|c|}{ Ознаки, що характери-зують: молочний тип } & 11 & $0,263 \pm 0,033^{3}$ & 9,90 & $0,049 \pm 0,036$ & 1,44 \\
\hline \multicolumn{2}{|c|}{ тулуб } & 11 & $0,126 \pm 0,035^{3}$ & 4,02 & $0,039 \pm 0,036$ & 1,14 \\
\hline \multirow{2}{*}{\multicolumn{2}{|c|}{ кінцівки }} & 13 & $0,067 \pm 0,043$ & 1,66 & $0,061 \pm 0,043$ & 1,49 \\
\hline & & 9 & $0,127 \pm 0,028^{3}$ & 5,09 & $0,020 \pm 0,029$ & 0,70 \\
\hline \multicolumn{2}{|l|}{ Загальна оцінка } & 8 & $0,218 \pm 0,23^{3}$ & 8,11 & $0,055 \pm 0,025$ & 1,52 \\
\hline \multicolumn{2}{|c|}{ Описові ознаки: висота } & 7 & $0,158 \pm 0,021^{3}$ & 8,83 & $0,027 \pm 0,021$ & 1,32 \\
\hline \multicolumn{2}{|c|}{ ширина грудей } & 6 & $0,039 \pm 0,018^{1}$ & 2,30 & $0,015 \pm 0,018$ & 0,86 \\
\hline \multicolumn{2}{|r|}{ глибина тулуба } & 6 & $0,149 \pm 0,017^{3}$ & 9,90 & $0,039 \pm 0,018$ & 2,32 \\
\hline \multicolumn{2}{|r|}{ кутастість } & 7 & $0,310 \pm 0,019^{3}$ & 21,1 & $0,017 \pm 0,021$ & 0,82 \\
\hline \multicolumn{2}{|r|}{ положення заду } & 7 & $0,010 \pm 0,021$ & 0,47 & $0,051 \pm 0,021$ & 2,50 \\
\hline \multicolumn{2}{|r|}{ ширина заду } & 7 & $0,139 \pm 0,021^{3}$ & 7,61 & $0,015 \pm 0,021$ & 0,72 \\
\hline \multicolumn{2}{|r|}{ кут скакального суглоба } & 8 & $0,194 \pm 0,024^{3}$ & 9,65 & $0,028 \pm 0,025$ & 1,16 \\
\hline \multicolumn{2}{|r|}{ постава тазових кінцівок } & 7 & $0,166 \pm 0,021^{3}$ & 9,36 & $0,008 \pm 0,021$ & 0,36 \\
\hline \multicolumn{2}{|r|}{ кут ратиць } & 8 & $0,101 \pm 0,025^{3}$ & 4,49 & $0,020 \pm 0,025$ & 0,81 \\
\hline \multicolumn{2}{|r|}{ переднє прикріплення вимені } & 7 & $0,186 \pm 0,021$ & 10,7 & $0,012 \pm 0,021$ & 0,57 \\
\hline \multicolumn{2}{|r|}{ висота вимені ззаду } & 8 & $0,144 \pm 0,024^{3}$ & 6,76 & $0,050 \pm 0,025$ & 2,12 \\
\hline \multicolumn{2}{|r|}{ центральна зв'язка } & 8 & $0,120 \pm 0,025^{3}$ & 5,49 & $0,014 \pm 0,025$ & 0,58 \\
\hline \multicolumn{2}{|r|}{ глибина вимені } & 7 & $0,029 \pm 0,021$ & 1,40 & $0,028 \pm 0,021$ & 1,35 \\
\hline \multicolumn{2}{|r|}{ розміщення передніх дійок } & 8 & $0,012 \pm 0,025$ & 0,47 & $0,026 \pm 0,025$ & 1,08 \\
\hline \multicolumn{2}{|r|}{ розміщення задніх дійок } & 8 & $0,013 \pm 0,025$ & 0,53 & $0,021 \pm 0,025$ & 0,86 \\
\hline \multicolumn{2}{|r|}{ довжина дійок } & 6 & $0,025 \pm 0,018$ & 1,47 & $0,009 \pm 0,018$ & 0,54 \\
\hline \multicolumn{2}{|r|}{ переміщення (хода) } & 7 & $0,131 \pm 0,021^{3}$ & 7,08 & $0,021 \pm 0,021$ & 1,01 \\
\hline \multicolumn{2}{|r|}{ вгодованість } & 8 & $0,063 \pm 0,0251$ & 2,72 & $0,041 \pm 0,075$ & 1,72 \\
\hline
\end{tabular}

Із низки описових ознак екстер'єру на величину надою корів-первісток досліджуваного стада ПЗ «Владана» вплив чинить ознака «кутастість» - 31,0\% при $\mathrm{P}<0,001$. За рештою 3 них встановлена помірна та низька сила впливу, показник якої варіював в межах 1,0-19,4\% з різним ступенем достовірності.
Вивчення сили впливу лінійних ознак на показники молочної продуктивності корів української червоно-рябої молочної породи племінного заводу «Маяк» та ТОВ «Млинівський комплекс» (табл. 3 та 4) засвідчило міжстадну різницю за більшістю з них.

\section{Сила впливу лінійних ознак на рівень розвитку молочної продуктивності корів-первісток} української червоно-рябої молочної породи ПЗ «Маяк»

(Ступені свободи $=250$ )

\begin{tabular}{|c|c|c|c|c|c|c|}
\hline & \multirow[b]{2}{*}{ Ознаки екстер'єру } & \multirow{2}{*}{$\begin{array}{l}\text { Число } \\
\text { градацій }\end{array}$} & \multicolumn{2}{|c|}{ Надій } & \multicolumn{2}{|c|}{ Жир, \% } \\
\hline & & & $\eta_{\mathrm{x}}^{2} \pm$ S.E. & $\mathrm{F}$ & $\eta_{\mathrm{x}}^{2} \pm$ S.E. & $\mathrm{F}$ \\
\hline Ознаки, що характ & ктери-зують: молочний тип & 10 & $0,257 \pm 0,035^{3}$ & 9,20 & $0,059 \pm 0,037$ & 1,68 \\
\hline & тулуб & 13 & $0,180 \pm 0,049^{3}$ & 4,34 & $0,039 \pm 0,051$ & 0,79 \\
\hline & кінцівки & 10 & $0,056 \pm 0,037$ & 1,59 & $0,023 \pm 0,037$ & 0,64 \\
\hline & вим'я & 10 & $0,204 \pm 0,036^{3}$ & 6,82 & $0,043 \pm 0,037$ & 1,20 \\
\hline Загальна оцінка & & 6 & $0,274 \pm 0,038^{3}$ & 10,6 & $0,057 \pm 0,040$ & 1,72 \\
\hline Описові ознаки: ви & висота & 8 & $0,149 \pm 0,028^{3}$ & 6,07 & $0,024 \pm 0,029$ & 0,86 \\
\hline & ширина грудей & 8 & $0,036 \pm 0,029$ & 1,29 & $0,064 \pm 0,029$ & 2,35 \\
\hline & глибина тулуба & 7 & $0,192 \pm 0,024^{3}$ & 9,60 & $0,039 \pm 0,025$ & 1,65 \\
\hline & кутастість & 7 & $0,465 \pm 0,019^{3}$ & 35,2 & $0,059 \pm 0,025$ & 2,52 \\
\hline & положення заду & 6 & $0,013 \pm 0,020$ & 0,62 & $0,066 \pm 0,020$ & 3,46 \\
\hline & ширина заду & 6 & $0,155 \pm 0,020^{3}$ & 8,95 & $0,027 \pm 0,020$ & 1,38 \\
\hline & кут скакального суглоба & 8 & $0,020 \pm 0,029$ & 0,71 & $0,058 \pm 0,029$ & 21,3 \\
\hline & постава тазових кінцівок & 8 & $0,169 \pm 0,028^{3}$ & 7,03 & $0,049 \pm 0,029$ & 1,79 \\
\hline
\end{tabular}




\begin{tabular}{|c|c|c|c|c|c|}
\hline \multirow[b]{2}{*}{ Ознаки екстер'єру } & \multirow{2}{*}{$\begin{array}{c}\text { Число } \\
\text { градацій }\end{array}$} & \multicolumn{2}{|c|}{ Надій } & \multicolumn{2}{|c|}{ Жир, \% } \\
\hline & & $\eta_{\mathrm{x}}^{2} \pm$ S.E. & $\mathrm{F}$ & $\eta_{x}^{2} \pm S . E$. & $\mathrm{F}$ \\
\hline кут ратиць & 7 & $0,028 \pm 0,025$ & 1,18 & $0,010 \pm 0,025$ & 0,39 \\
\hline переднє прикріплення вимені & 6 & $0,155 \pm 0,020^{3}$ & 8,92 & $0,004 \pm 0,020$ & 0,21 \\
\hline висота вимені ззаду & 8 & $0,050 \pm 0,029$ & 1,84 & $0,025 \pm 0,029$ & 0,90 \\
\hline центральна зв'язка & 9 & $0,123 \pm 0,033^{3}$ & 4,24 & $0,021 \pm 0,033$ & 0,66 \\
\hline глибина вимені & 8 & $0,086 \pm 0,029^{2}$ & 3,25 & $0,036 \pm 0,029$ & 1,30 \\
\hline розміщення передніх дійок & 8 & $0,052 \pm 0,029$ & 1,89 & $0,017 \pm 0,029$ & 0,61 \\
\hline розміщення задніх дійок & 8 & $0,042 \pm 0,029$ & 1,50 & $0,024 \pm 0,029$ & 0,86 \\
\hline довжина дійок & 7 & $0,023 \pm 0,025$ & 0,95 & $0,016 \pm 0,025$ & 0,67 \\
\hline переміщення (хода) & 7 & $0,101 \pm 0,024^{3}$ & 4,57 & $0,032 \pm 0,025$ & 1,33 \\
\hline вгодованість & 7 & $0,296 \pm 0,023^{3}$ & 17,0 & $0,041 \pm 0,025$ & 1,74 \\
\hline
\end{tabular}

Найвищий ступінь впливу на мінливість надою первісток ПЗ «Маяк» і ТОВ «Млинівський комплекс» спричинили ознаки, що характеризують молочний тип
$(25,7 \%$ і $26,8 \%)$, вим'я $(20,4 \%$ і $30,9 \%)$ та загальна оцінка за екстер'єрний тип $(27,4 \%$ і $29,5 \%)$ відповідно.

Таблиця 4

Сила впливу лінійних ознак на рівень розвитку молочної продуктивності корів-первісток української червоно-рябої молочної породи стада «Млинівський комплекс»

(Ступені свободи = 187)

\begin{tabular}{|c|c|c|c|c|c|}
\hline \multirow[b]{2}{*}{ Ознаки екстер'єру } & \multirow{2}{*}{$\begin{array}{c}\text { Число } \\
\text { градацій }\end{array}$} & \multicolumn{2}{|c|}{ Надій } & \multicolumn{2}{|c|}{ Жир, \% } \\
\hline & & $\eta_{x}^{2} \pm$ S.E. & $\mathrm{F}$ & $\eta_{x}^{2} \pm S . E$. & $\mathrm{F}$ \\
\hline Ознаки, що характери-зують: молочний тип & 12 & $0,268 \pm 0,058^{3}$ & 5,83 & $0,123 \pm 0,062$ & 2,23 \\
\hline $\begin{array}{cc}\text { тулуб } \\
\end{array}$ & 14 & $0,229 \pm 0,068^{3}$ & 5,68 & $0,029 \pm 0,075$ & 0,40 \\
\hline кінцівки & 13 & $0,220 \pm 0,066^{3}$ & 4,09 & $0,056 \pm 0,069$ & 0,86 \\
\hline вим'я & 15 & $0,309 \pm 0,074^{3}$ & 5,49 & $0,077 \pm 0,081$ & 1,02 \\
\hline Загальна оцінка & 12 & $0,295 \pm 0,71^{3}$ & 5,68 & $0,062 \pm 0,072$ & 1,33 \\
\hline Описові ознаки: висота & 9 & $0,236 \pm 0,042^{3}$ & 6,87 & $0,082 \pm 0,045$ & 1,98 \\
\hline ширина грудей & 7 & $0,064 \pm 0,033$ & 2,04 & $0,076 \pm 0,033$ & 2,47 \\
\hline глибина тулуба & 8 & $0,237 \pm 0,037^{3}$ & 7,92 & $0,071 \pm 0,039$ & 1,94 \\
\hline кутастість & 6 & $0,278 \pm 0,025^{3}$ & 13,9 & $0,027 \pm 0,028$ & 1,00 \\
\hline положення заду & 6 & $0,049 \pm 0,028$ & 1,87 & $0,026 \pm 0,028$ & 1,02 \\
\hline ширина заду & 9 & $0,350 \pm 0,039^{3}$ & 12,0 & $0,015 \pm 0,045$ & 0,33 \\
\hline кут скакального суглоба & 6 & $0,024 \pm 0,039$ & 0,62 & $0,027 \pm 0,028$ & 1,05 \\
\hline постава тазових кінцівок & 8 & $0,264 \pm 0,036^{3}$ & 9,16 & $0,024 \pm 0,039$ & 0,63 \\
\hline кут ратиць & 8 & $0,231 \pm 0,037^{3}$ & 7,69 & $0,044 \pm 0,039$ & 1,18 \\
\hline переднє прикріплення вимені & 9 & $0,388 \pm 0,038^{3}$ & 14,1 & $0,081 \pm 0,045$ & 1,97 \\
\hline висота вимені ззаду & 9 & $0,237 \pm 0,042^{3}$ & 6,93 & $0,065 \pm 0,045$ & 1,55 \\
\hline центральна зв'язка & 9 & $0,231 \pm 0,043^{3}$ & 6,67 & $0,024 \pm 0,044$ & 0,54 \\
\hline глибина вимені & 7 & $0,054 \pm 0,033$ & 1,71 & $0,085 \pm 0,033$ & 2,80 \\
\hline розміщення передніх дійок & 7 & $0,120 \pm 0,033^{3}$ & 4,09 & $0,046 \pm 0,033$ & 1,46 \\
\hline розміщення задніх дійок & 8 & $0,093 \pm 0,039^{1}$ & 2,61 & $0,037 \pm 0,039$ & 0,98 \\
\hline довжина дійок & 7 & $0,051 \pm 0,033$ & 1,61 & $0,038 \pm 0,033$ & 1,19 \\
\hline переміщення (хода) & 8 & $0,218 \pm 0,037^{3}$ & 7,13 & $0,091 \pm 0,039$ & 2,56 \\
\hline вгодованість & 7 & $0,112 \pm 0,033^{2}$ & 3,81 & $0,025 \pm 0,033$ & 0,75 \\
\hline
\end{tabular}

3 описових ознак найвищою мірою надій корівпервісток стада ПЗ «Маяк» залежить від глибини тулуба ( $\left.\eta_{\mathrm{x}}^{2}=0,192 ; \mathrm{P}<0,001\right)$, кутастості $\left(\eta_{\mathrm{x}}^{2}=0,465 ; \mathrm{P}<0,001\right)$ та вгодованості $\left(\eta_{\mathrm{x}}^{2}=0,296 ; \quad \mathrm{P}<0,001\right)$. Продуктивність за надоєм тварин ТОВ «Млинівський комплекс» на достатньо високому рівні залежить від наступних описових ознак: висоти переднього та заднього прикріплення вимені $\left(\eta_{\mathrm{x}}^{2}\right.$ $=0,388$ та $\eta_{\mathrm{x}}^{2}=0,238$ відповідно; $\left.\mathrm{P}<0,001\right)$, розвитку центральної зв'язки ( $\left.\eta_{\mathrm{x}}^{2}=0,231 ; \mathrm{P}<0,001\right)$, ширини заду $\left(\eta_{\mathrm{x}}^{2}\right.$ $=0,350 ; P<0,001)$.

Згідно результатів наших досліджень істотного впливу лінійних ознак на вміст жиру в молоці корів-первісток обох підконтрольних господарств виявлено не було. Сила впливу досліджуваних факторів варіювала в межах 0,4\% (переднє прикріплення вимені) - 12,3\% (молочний тип).

Таким чином, встановлена наявність достовірного впливу лінійних ознак на величини надою корів-первісток свідчить про ефрективність селекції українських чорно-рябої та червоно-рябої молочних порід за добором та підбором предків з високою оцінкою лінійної класифікації.

Висновки. За результатами лінійної класифікації корів-первісток підконтрольних стад 3 розведення української чорно-рябої та червоно-рябої молочних порід Центрального та Північно-Східного регіонів України встановлено достовірний вплив на рівень надою лінійних групових ознак, які характеризують вираженість молочного типу, розвиток тулуба та морфологічних ознак вимені. Фінальна оцінка за тип справляє вплив на надій з силою від $21,8 \%$ до $34,4 \%$.

Показники дисперсійного аналізу свідчать, що 
величина надою корів-первісток підконтрольних стад достатньою мірою залежить від рівня оцінки описових ознак, особливо таких як висота, глибина тулуба, кутастість, ширина заду, постава тазових кінцівок, переднє та заднє прикріплення вимені, центральна зв'язка та переміщення.

Вміст жиру в молоці не залежить від рівня оцінки як групових, так і описових ознак. 


\section{Список використаної літератури:}

1. Буркат В.П., Полупан Ю.П., Йовенко І.В. Лінійна оцінка корів за типом. К. : Аграр. наука, 2004. 88 с.

2. Ладика В.І., Хмельничий Л.М., Салогуб А.М. Сполучна мінливість статей екстер'єру корів з молочною продуктивністю. Збірник наукових праць Білоцерківського НАУ Технологія виробництва $і$ переробки продукції тваринництва. Біла Церква, 2010. Вип. 3 (72), С. 9-11.

3. Меркурьева Е.К. Генетические основы селекции в скотоводстве. М.: Колос, 1977. 240 с.

4. Хмельничий Л.М., Ладика В.І., Полупан Ю.П., Салогуб А.М. Методика лінійної класифікації корів молочних і молочно-м'ясних порід за типом. Суми : ВВП “Мрія-1” ТОВ, 2008. 28 с.

5. Плохинский Н. А. Наследуемость. Новосибирск, 1964. 196 с.

6. Полупан, Ю. П. Повторяемость и взаимосвязь инструментальной и глазомерной оценки экстерьера крупного рогатого скота. Сельскохозяйственная биология. 2000. № 2, С. 108-114.

7. Полупан Ю.П. Онтогенетичні та селекційні закономірності формування господарськи корисних ознак молочної худоби : дис. ... доктора с.-г. наук : 06.02 .01 / [Ін-т розведення і генетики тварин НААН]. - с. Чубинське Київської обл., 2013. $694 \mathrm{c}$.

8. Ладика В.І., Хмельничий Л.М., Буркат В.П., Рубан С.Ю. Реєстрація ICAR: довідник. Суми : СНAУ, 2010. 457 с.

9. Хмельничий Л.М. Успадковуваність та кореляційна мінливість лінійних ознак екстер'єру корів-первісток української червоно-рябої молочної породи Черкащини. Науково-інфрормаційний. Вісник Херсонського державного аграрного університету. Херсон. 2018. Вип. 11, С. 73-75.

10. Хмельничий Л.М., Вечорка В.В. Життєздатність корів українських чорно-рябої та червоно-рябої молочних порід залежно від оцінки лінійних ознак екстер'єру. Вісник Сумського національного аграрного університету. Серія «Тваринниитво». 2017. Вип. 7 (33), С. 48-58.

11. Хмельничий Л.М., Вечорка В.В. Особливості будови тіла корів української чорно-рябої молочної та голштинської порід. Розведення і генетика тварин. 2008. Вип. 42, С. 318 - 326.

12. Хмельничий Л.М., Вечорка В.В. Сполучена мінливість промірів та індексів будови тіла з надоєм корів української чорно-рябої молочної породи. Розведення і генетика тварин. 2015. Вип. 50, С. 96-102.

13. Хмельничий Л.М., Вечорка В.В. Тривалість життя корів української червоно-рябої молочної породи залежно від оцінки лінійних ознак. Розведення і генетика тварин. 2017. Вип. 53,С. 197-208.

14. Хмельничий Л.М., Вечёрка В.В. Наследуемость признаков линейной оценки типа коров украинских молочных пород. Генетика и разведение животных: Санкт-Петербург, Пушкин, «ООО Борвик Полиграфия». 2016. № 4. С.57-61.

15. Хмельничий Л.М., Салогуб А.М., Хмельничий С.Л., Лобода А.В. Співвідносна мінливість та успадковуваність лінійних ознак екстер'єру корів сумського внутрішньопородного типу української чорно-рябої молочної породи. Вісник Сумського національного аграрного університету. Серія «Тваринництво». 2018. Вип. 2 (34), С. 92-96.

16. Berry D. P., Harris B. L., Winkelman A.M., Montgomerie W. Phenotypic associations between traits otherthan production andl ongevity in New Zealand dairy cattle. Journal of Dairy Science. 2005. v.88, p. 2962-2974.

17. ICAR Recording Guidelines approved by the General Assembly held in Berlin, Germany, on May 2014. Copyright: 2014, ICAR. 618 p.

18. Onyiro O.M., Brotherstone S. Genetic Analysis of Locomotion and Associated Conformation Traits of HolsteinFriesian Dairy Cows Managed in Different Housing Systems. Journal of Dairy Science, 2008. Vol. 91, Issue 1, p. 322-328.

19. Wiggans, G.R., Thornton L.L.M., Neitzel R.R., Gengler N. Genetic Parameters and Evaluation of Rear Legs (Rear View) for Brown Swiss and Guernseys. Journal of Dairy Science, 2006. Vol. 89, Issue 12, p.4895-4900.

20. Zavadilová L., Němcová E., Štípková M., Bouška J. Relationships between longevity and conformation traits in Czech Fleckvieh cows. Czech J. Anim. Sci., 54, 2009 (9): 387-394.

\section{References:}

1. Burkat, V. P., Polupan, Y. P. and Yovenko, I. V., 2004. Liniyna otsinka koriv za typom [Linear estimation cows by type]. Agrarian Science, Kyiv.

2. Ladyka, V. I., Khmelnychyi, L. M. and Salohub, A. M., 2010. Spoluchna minlyvist' statey ekster'yeru koriv z molochnoyu produktyvnistyu [Connective variability of cows conformation traits with milk productivity]. Zbirnyk naukovykh prats Bilotserkivskoho NAU. Tekhnolohiia vyrobnytstva i pererobky produktsii tvarynnytstva. Bila Tserkva, issue 3(72), pp. 9-11.

3. Merkureva, E. K., 1977. Geneticheskie osnovy seleksii v skotovodstve [Genetic principles of selection in livestock]. M.: Kolos.

4. Khmel'nychyy, L. M., Ladyka, V. I., Polupan, Yu. P. and Salohub, A. M., 2008. Metodyka liniynoyi klasyfikatsiyi koriv molochnykh i molochno-m'yasnykh porid za typom [The method of linear classification cows of dairy and dairy-beef breeds by type]. Sumy: "Mriya-1".

5. Plokhinskiy, N. A., 1964. Nasleduemost' [Heritability]. Novosibirsk.

6. Polupan, Yu. P., 2000. Povtoryaemost' i vzaimosvyaz' instrumental'noy i glazomernoy otsenki ekster'era krupnogo rogatogo skota [Repeatability and relationship of instrumental and visual assessment of cattle]. Sel'skokhozyaystvennaya biologiya, no. 2, pp. 108-114.

7. Polupan, Yu. P., 2013. Ontogenetic and breeding regularities formation of economically useful traits of Dairy cattle. Thesis of the doctor of agricultural sciences. Institute of Animals breeding and Genetics NAAS. Chubynske.

8. Ladyka, V. I., Khmel'nychyi, L. M., Burkat, V. P. and Ruban, S. Yu., 2010. Reyestratsiya ICAR. Dovidnyk [Registration ICAR. Reference book]. Sumy: Sums'kyy Natsional'nyy Ahrarnyy Universytet. 457.

9. Khmelnychyi, L. M., 2018. Uspadkovuvanist' ta korelyatsiyna minlyvist' liniynykh oznak ekster"yeru koriv-pervistok ukrayins'koyi chervono-ryaboyi molochnoyi porody Cherkashchyny [Herinability and correlative variability of conformation linear 
traits of first-born cows of Ukrainian Red-and-White dairy breed in Cherkasy region]. Visnyk Khersonskoho derzhavnoho ahrarnoho universytetu. Kherson, issue 11, pp. 73-75.

10. Khmelnychyi, L. M., and Vechorka, V. V., 2017. Zhyttiezdatnist koriv ukrainskykh chorno-riaboi ta chervono-riaboi molochnykh porid zalezhno vid otsinky liniinykh oznak eksterieru [Viability of cows of Ukrainian Black- and Red-and-White dairy breeds depending on the assessment of linear traits of the conformation]. Visnyk Sumskoho natsionalnoho ahrarnoho universytetu. Seriia "Tvarynnytstvo», issue 7(33), pp. 48-58.

11. Khmelnychyi, L. M. and Vechorka, V. V., 2008. Osoblyvosti budovy tila koriv ukrayins'koyi chorno-ryaboyi molochnoyi ta holshtyns'koyi porid [Features of the body structure cows of Ukrainian Black-and-White dairy and Holstein breeds]. Rozvedennia i henetyka tvaryn, issue 42, pp. 318-326.

12. Khmelnychyi, L. M. and Vechorka, V. V., 2015. Spoluchena minlyvist' promiriv ta indeksiv budovy tila z nadoyem koriv ukrayins'koyi chorno-ryaboyi molochnoyi porody [Correlative variability of measurements and body structure indexes with cow's milk yield of Ukrainian Black-and-White dairy breed]. Rozvedennia i henetyka tvaryn, issue 50, pp. 96-102.

13. Khmelnychyi, L. M. and Vechorka, V. V., 2017. Tryvalist zhyttia koriv ukrainskoi chervono-riaboi molochnoi porody zalezhno vid otsinky liniinykh oznak [Life expectancy of cows of the Ukrainian Red-and-White dairy breed, depending on the assessment of linear traits]. Rozvedennia i henetyka tvaryn, issue 53, pp. 197-208.

14. Khmel'nichiy, L. M. and Vecherka, V. V., 2016. Nasleduemost' priznakov lineynoy otsenki tipa korov ukrainskikh molochnykh porod [Heritability of a linear type traits assessment of cows of Ukrainian dairy breeds]. Genetika $i$ razvedenie zhivotnykh: Sankt-Peterburg, Pushkin, «000 Borvik Poligrafiya», no. 4, pp. 57-61.

15. Khmel'nychyi, L. M., Salohub, A. M., Khmel'nychyi, S. L. and Loboda, A.V., 2018. Spivvidnosna minlyvist' ta uspadkovuvanist' liniynykh oznak ekster'yeru koriv sums'koho vnutrishn'oporodnoho typu ukrayins'koyi chorno-ryaboyi molochnoyi porody [Correlative variability and heritability of linear traits of the conformation, cow's of the Sumy intrabreed type of the Ukrainian Black-and-White dairy breed]. Visnyk Sumskoho natsionalnoho ahrarnoho universytetu. Seriia "Tvarynnytstvo», issue 2 (34), pp. 92-96.

16. Berry, D.P., Harris, B.L.; Winkelman, A.M., and Montgomerie, W., 2005. Phenotypic associations between traits other than production and longevity in New Zealand dairy cattle. Journal of Dairy Science, issue 88, pp. 2962-2974.

17. ICAR Recording Guidelines approved by the General Assembly held in Berlin, Germany, on May 2014. Copyright: 2014, ICAR. 618.

18. Onyiro, O.M., and Brotherstone S., 2008. Genetic Analysis of Locomotion and Associated Conformation Traits of Holstein-Friesian Dairy Cows Managed in Different Housing Systems. Journal of Dairy Science, Vol. 91, issue 1, pp.322-328.

19. Wiggans, G.R., Thornton L.L.M., Neitzel R.R., and Gengler N., 2006. Genetic Parameters and Evaluation of Rear Legs (Rear View) for Brown Swiss and Guernseys. Journal of Dairy Science, vol. 89, issue 12, pp. 4895-4900.

20. Zavadilová, L., Němcová E., Štípková M., and Bouška J., 2009. Relation ships between longevity and conformation traits in Czech Fleckvieh cows. Czech Journal of Dairy Science, issue 54(9), pp. 387-394.

\section{Khmelnychyi Leontiy Mykhailovych, Doctor of Agricultural Sciences, Professor Vechorka Victoria Viktorivna, Doctor of Agricultural Sciences, Professor \\ Sumy National Agrarian University (Sumy, Ukraine)}

The influence of linear conformation traits on the condition of milk productiviti of cows firstborn Ukrainian black-and-white and red-and-white dairy breeds

The researches were conducted in the aspect of determining the degree of influence of linear traits on the level of milk productivity of cows of Ukrainian dairy breeds. Experimental data were based on materials obtained in herds of pedigree farms for breeding Ukrainian Black-and-White dairy breed of AF "Mayak" in Zolotoniskyi district of Cherkasy region and LLC "Vladana" Sumy district in Sumy region and farms for breeding of Ukrainian Red-and-White dairy breed of PF AF "Mayak" Cherkasy region and LLC "Mlynivskyi complex" Romenskyi district in Sumy region.According to the variance analysis, found reliable influence of three groups of linear traits and overall assessment on a 100-point scale by the amount of milk yield of cows firstborn for 305 days of lactation. The milk yield of the firstborn of Ukrainian Black-and-White dairy breed of the "Mayak" pedigree farm depended on $33.2 \%$ of traits that characterize the dairy type in the complex, $20.6 \%$ - development of the body and $19.9 \%$ - morphological traits of the udder. An analysis of the power of influence of linear traits on the milk productivity level of the PF "Vladana" cows showed a reliable influence of group complexes of traits characterizing the dairy type, body and udder to yield, respectively $26.3 \%, 12.6 \%$ and $12.7 \%$.

According to cows assessment of Ukrainian Red-and-White dairy breed, the highest degree of influence on the milk yield variability of the firstborn of "Mayak" and LLC "Mlynivskyi complex" was due traits characterizing the dairy type on (25.7\% and $26.8 \%)$, udder (20.4\% and $30.9 \%)$ and the overall estimation for conformation type (27.4\% and $29.5 \%)$, respectively.

Indicators of variance analysis showed that the milk yield of firstborn cows of both breeds in controlled herds also sufficiently depending on the level of descriptive traits estimation, especially such as height, body depth, angularity, rear width, front and rear udder attachment, central ligament, and locomotion. The fat content of milk didn't depend on the score level of both group and descriptive traits. The presence of influence of linear traits on the milk yield of firstborn cows testified to the effectiveness of breeding of Ukrainian Black-and-White and Red-and-White dairy breeds estimated by the method of linear classification.

Key words: Black-and-White dairy, Red-and-White dairy, power of influence, linear type estimation, yield, firstborn cow.

Дата надходження до редакції: 01.02.2020 p. 
